\title{
The methodological aspect of the landscape and ecological forming of a comfortable environment for the Smart City
}

\author{
Nina Ivanova ${ }^{1, *}$, Olga Ganzha ${ }^{1}$ \\ ${ }^{1}$ Volgograd State Technical University, Lenin ave, 28, Volgograd, 400005, Russia
}

\begin{abstract}
The research is directed to the development of a model for the "smart city" including an interior space with the developed system of information technologies to provide comfortability in the area of living environment and the natural external envelope forming a hurdle from negative natural and climatic phenomena. Some new landscape solutions are given that increase the potential of energy saving technologies in the city when later transforming it into the Smart city. The history of building the green belt around Stalingrad-Volgograd is analyzed, directions of the ecological type of their impact on the urban living quality are settled. New landscape solutions are presented increasing the potential of energy saving technologies of the city. The research embrace the theoretical principles of forming the landscape building objects in the concept of the Smart city. The article justifies the need for enlarging the landscape building techniques in terms of enhancing the energy efficiency of buildings as well as forming the territorial platform to transform the city into the "Smart city" region. The developed methodology of the landscape object building enables to apply the obtained proposals in the Russian and world construction under similar natural conditions when developing the city into the Smart city sphere.
\end{abstract}

\section{The Introduction}

The international practice in the city planning has accumulated a considerable experience in the development of modern information technologies when forming the concept of the Smart Cities, in particular, the directions of the energy efficiency of buildings. The elements of the "green architecture" are widely used.

Recently, the application of landscape solutions in the climatic potential of the environment is of interest, for example, vertical gardening of buildings' facades enabling to reduce power costs and others. For the regions with arid climates (Volgograd belongs to them), the striving to create comfortable living conditions becomes a major energy saving measure where the landscape building plays an active role in the buildings' energy efficiency. The techniques of wall gardening (overshadowing, wall cooling) and the

*Corresponding author: ivanovaninav@mail.ru 
construction of the outer landscape environment are targeted at forming favorable urban conditions for the Smart city.

\subsection{The objectives of the investigation}

The objective of the research is the feasibility of the regional character of the landscape solutions in the construction of the green belt in the Smart city concept. The tasks of the research:

-the analysis of the character of the landscape construction in the Smart city concept;

-the research into the historic stages in the construction of the green belt around the cities and allocation of areas of the impact on the urban environment by the example of Volgograd;

-the development of landscape building principles in the Smart city sphere and compiling a model of the Smart city with the outer green environment;

- carrying out the experimental development on designing the "green belt" when transforming the city into the "Smart city" by the example of Volgograd.

\subsection{The practical and theoretical base of the work}

The search for solution of general and complex problems of forming the Smart city concept encounters with various positions in a number of special journals. When starting their research, the authors specify the terms since both in Russia and in the world, there is no precise definition (known are "the digital city», "the city of knowledge, et al.). The following definitions are detected: the term "smart city" defines the use of big data volumes (Big Data), compiled and processed using contemporary technologies aiming at optimization and organization of the urban environment and becomes an ecologically friendly object; or "smart cities" can be considered as the concept of "megalopolises actively introducing modern technologies to ensure a sustainable development and ecological safety for a more comfortable life of their citizens » [1].

In terms of the landscape and ecological construction, the Smart city acts as an "ecocity" with efficient economy, high level of urban living quality, well-thought-out solutions aiming at the environmental friendliness.

The concept of the very idea of developing new Smart cities becomes one the topics under discussion in the engineering community and is connected to the research on designing telecommunication systems $[2,3]$, the works on the program engineering and the graphical analysis of software metrics [4], and other in the information technologies.

The many works are devoted to the development and application of the smart systems in the city, the special attention is given to the enhancement of efficiency of the urban ecological conditions by way of discovery of the needed types of smart technologies and their connection with the solution of the ecological issues in the life environment (smart trash bins, trash containers working from the solar energy, using the technology of trash pressing, and others) [5]. The examples of such smart systems are given in Barcelona, Copenhagen, and other places where the unification of the whole urban economy is the target, starting from the illumination and parking up to energy systems and the object of commercial nature [6]. However, the authors point out that it is not only the achieving of the ecological comfort in a new city that attracts people; the important issues are the ones of the cultural identity, forming a city-planning strategy preserving the local context and architectural traditions. These statements are discussed by the American researcher Chris Hartley using the materials of new Asian developing cities [7]. The author analyzing the existing city planning shows that the label «the smart city» often accompanies the old principles of city planning and the standard ways of planning without regard to the culture, social ties. The 
trend of further perspectives for the smart city development is revealed in the work «The Smart city as perspectives and trends of development», where the smart city acts as a vector of the further social and economic development [8]. The research done by Ingeborg Rocker deals with the future planning, in her opinion, cities should be planned as living organisms, to each applying its own technique [9]. This principle is applied to the creation of many «Smart cities», with living spaces of the social and technological environment and fitted out with modern intellectual means. At present, more than 100 "intellectual" cities are being built in the world. Among the Russian cities, these include Skolkovo [10], the main concept of its building was the creation of the environment promoting an intensive development of innovation and technological entrepreneurship. The "Smart city" planning contributed to the creation of an experimental site for developing and acceptance of new technologies which later will be able to do the rounds and to be introduced in Russian cities and abroad $[11,12]$.

The construction of new and the transformation of the existing cities into the "Smart cities" sphere is taking place in various natural and climatic zones. The studies $[13,14]$ are devoted to the problem of planning and developing the smart technologies under the hard natural environment. The studies are targeted at the Far North lands to design the unique concepts for the communities there, environmental improvement, search for alternative energy sources, creation of the information field and others [13]. The author while solving compositional features in the Northern smart cities planning pointed out the contemporary compositional trends in the construction under the difficult climate conditions: building the cities of a limited size and with specific parameters (Songdo, Masdar); some additional development points are forming areas with strong infrastructure (« system cities», the project of the Island 2100). The city planning decision to create a shield against the negative impact of the climate was being developed in the project "The Masdar Initiative" where the planners assume to build a high wall around the whole urbane zone in order to protect it from the hot desert wind. The smart technologies are taken into account which will «enable to split an urban zone into many shadowy streets along which a light cool wind will be blowing» [14].

«The Smart» cities have already become a reality, some examples of realizing the concept of "smart" cities: Neapolis (Cyprus), Songdo and Inchkhon (South Korea), Djazzan (Saudi Arabia), Lavasa (India), Usi, Khushan, Dongtan (China), Masdar (UAE), the Valley PlanIT (Portugal). The authors point at some hurdles in the design of the modernization programs (limited budgets, geographic boundaries, the organizational structure), as well as the absence of the corresponding expertise and the difficulty in the environmental compliance [15]. The smart cities development is tied to the high technology approaches in designing with the regard to the requirements of ecology, energy saving technologies. The national norms for the "green construction" are aimed at the adaptation of the international requirements of the energy-efficient building to the local conditions [16, 17]. Among the international norms of environmental compatibility in city planning and architecture, the authors point out LEED, BREEAM, DGNB, having the main criteria for the assessment of the environment compatibility of an architectural structure: the location ecology; water supply and preservation; atmosphere and energy; resources and materials; water quality; noise pollution level [16]. In the article [17], the author analyzes the instances of the «technology of the literate architectural engineering taking into account the local environmental resources» («Eco-house Solar-5», «Panda House»), in the bioclimatic approach in the design. The study [18] shows the problems of using territorial and space reserves and forecasting the city planning regulation of the city planning pattern in Samara.

The green architecture (green economy) is treated in the articles as a base of the sustainable development of the "smart city". The innovative green techniques are analyzed based on the energy and resource saving, clean transportation, alternative energy sources 
and others enabling to preserve nature and the ecological well-being of humans [19]. The interest is aroused by the questions of applying the energy saving technologies and methods of enhancing the energy efficiency of buildings (energy saving paintwork and roof, solar batteries etc.) and the application of landscape solutions (vertical gardening of the southern facades and roof gardening) enabling to cut power costs. The practice of the project proposals for energy saving is revealed when arranging green plantation for cladding, green spacing on the upper levels of buildings and structures [20], the development of the building areas.

The preservation of the natural landscape, the natural surface of the earth, along with plant-soil cover and other components of the landscape is the basis for creating high-quality living environment and maintain ecological balance. The use of unsuitable areas for development allows to maintain urban landscapes. The concept of using underground space for construction of various civil purposes includes the main approaches and principles of creating a "smart" food-grade, biodegradable building, able to create favourable external and internal conditions of the living environment [25].

\section{The method for "the assessment of the environmental sustainability of the landscape"}

\subsection{Determining the general state of the landscape by the stability level}

In accordance with the methodology proposed by V.A. Baranov [21], the Volgograd municipal wood farm - the coefficients of ecological stability level CESL ${ }_{1}$ and $\mathrm{CESL}_{2}$ have been defined.

The coefficient $\mathrm{CESL}_{1}$ is based on the defining and comparison of the areas occupied by various landscapes. The coefficient $\mathrm{CESL}_{2}$ assesses the landscape with the regard to the impact of its biotic elements, their inner properties and the quality state. The assessment is done by the verbal scale (Table 1).

Table 1. The landscape stability characterization

\begin{tabular}{|c|c|c|c|}
\hline \multicolumn{4}{|c|}{ The coefficient of the ecological stability $\left(\mathrm{CESL}_{1}, \mathrm{CESL}_{2}\right)$} \\
\hline $\mathrm{CESL}_{1}$ & $\begin{array}{c}\text { Landscape } \\
\text { characterization }\end{array}$ & $\mathrm{CESL}_{2}$ & $\begin{array}{c}\text { Landscape } \\
\text { characterization }\end{array}$ \\
\hline$\leq 0,5$ & $\begin{array}{c}\text { Instability is well } \\
\text { expressed }\end{array}$ & $\leq 0,33$ & Instable \\
\hline $0,51-1,00$ & State is instable & $0,34-0,50 \mathrm{r}$ & fragile \\
\hline $1,01-3,00$ & State is nominally stable & $0,51-0,66$ & Stable stable \\
\hline 3,00 & $\begin{array}{c}\text { And the stability is well } \\
\text { expressed }\end{array}$ & $\begin{array}{c}\text { More than } \\
0,66\end{array}$ & \multicolumn{2}{c}{} \\
\hline
\end{tabular}

\subsection{Determining the landscape state by the level of stability on the basis of the characteristics of the ecological value of the its individual biotic elements}

The research has been done on the territory of the Volgograd municipal wood farm. The wood area of the municipal wood farm in Volgograd is the region of steppes on the European part of the Russian Federation. By the forest site mapping, all the wooden areas 
are located in the steppe site zone. According to Articles 10 and 102 of the Forest Code of the Russian Federation subject to its designated purpose, they belong to the shelter belt forests with the functions of nature and other objects protection. With respect to the General plan of Volgograd City for the years 2008-2025 and the guidelines in the Strategic plan of the sustainable development of Volgograd up to the year 2025, two categories of protection forests are separated which includes municipal woods with the total area of 13269,3 ha and the forests located in the first, second and third zones of the sanitary protection in the health and recreation areas and resorts with the area of 569,9 ha [21].

The main purpose of municipal forests is an environmental, water protection and barrier functions. The land use management structure for the territory of the Volgograd municipal wood farm is given in Table 2.

Table 2. The land use structure for the area of the Volgograd municipal wood farm

\begin{tabular}{|r|c|c|}
\hline No & Types of land use & Area, ha \\
\hline 1. & Total land area & 13839,2 \\
\hline 2. & Wooden lands (covered with forest vegetation) & 6482,9 \\
\hline 3. & $\begin{array}{c}\text { Forest cultures, } \\
\text { included conifer forest } \\
\text { leafed forest }\end{array}$ & $\begin{array}{c}2853,9 \\
26,0 \\
130,0\end{array}$ \\
\hline 4. & Natural grasslands, pastures & 19,8 \\
\hline 5. & Hay-fields & 340,8 \\
\hline 6. & Specially protected natural areas & 3626,0 \\
\hline 7. & Sands & 2070,9 \\
\hline 8. & Roads, narrow clearings & 121,5 \\
\hline 9. & Waters & 66,3 \\
\hline 10. & Wetlands & 485,3 \\
\hline 11. & Farms & 599,5 \\
\hline 12. & Other lands & 1005,2 \\
\hline
\end{tabular}

The share of forest lands is $61,7 \%$ of the wood farm territory. For the forests located at the boundary of the urban district, this is not a high percentage which shows the ability of woodlands to perform protective and ecological functions. Covered with forest vegetation, they amount to $55,5 \%$. Non-forest areas take up 38, $3 \%$ of all wood farm territory. The fifth part of non-forest areas ( $8,4 \%$ of the wood farm territory) features the protective zones of communications and utilities lines, landscape forest meadows, steep slopes and fireproof breaks. By the general plan of the city, some functional zones in the city are planned to be enlarged: living, production and other zones which will be located on the territory belonging to the municipal woods.

As a result of the calculations, it was established that the value of the coefficient $\mathrm{CESL}_{1}$ makes - 3, 46 which confirms a well-expressed landscape stability; the factor value $\mathrm{CESL}_{2}$ makes $-0,1$, which characterizes the wood farm territory as non-stable, therefore, the 
transformation of elements should be done into the stable ones. The non-stable elements include - built-on area, slopes, sands, lands with unstable grass cover. The complex of measures to increase the stability of the biotic elements will enable to rationally use the landscape, to preserve the environmental values and to prevent the possible loss of the wooden areas in the municipal forests.

\section{The development of the experimental}

\subsection{The natural and climate potential of the area}

The Volgograd Region is located in the south-east of Russia, all major natural areas of the arid zone are represented in its composition - chernozem steppe, dry steppe, and semidesert, the territory where dryness and dry hot winds occur, dust whirls and water erosion. In the direction from north-west to south-east, the northern steppe with its common chernozem is quickly changed by the southern chernozem and dry steppe with dark brown and chestnut soils. The extreme south-east of the region belongs to semi-deserts with its typical light-brown soils. Along with the general dryness of the climate, in some years, there are severe droughts: pre-vernal, spring- and- summer, late summer or autumn, as well as enduring (long-duration). The insufficient moisture, solonetzicity, sometimes solonchaklike soils, the unfavorable physical properties of soils - all these create great difficulties when choosing tree species and their cultivation. In the composition of the regional soils, there are considerable areas of sands and sandy soils: the presence of a large massif of Archedinsky-Donskie sands in the north and north-west of the region, the Don terrace sands in some districts of the region, the Volga sand belt along the high right bank of the Volga river - all these are sandy soils of little use. Afforestation works give positive results in reinforcement and protection of the easily blown-away soil against the soil retirement, fixation of shifting sands.

\subsection{Creation of the green belt in Volgograd (Stalingrad)}

The measures to build protective woods on the territory of the Volgograd region had been taken by the $19^{\text {th }}$ century: the Forest Department Committee of the Russian state and its Donskoi management decided in 1879 to reforest the Archeda-Don sands in order to reinforce broken sands that periodically covered fertile soils, roads and villages. In the 1930 -s there were created field protective and ravine forest belts on the agricultural lands, the reforesting of ravines and sands began in the early $20^{\text {th }}$ century (1903-1904), - tree and bush planting on the terraces and slopes of ravines to prevent their growth [22]. This period saw forest planting in the area of the Yergeni Hills - the largest plantation out of the built on the territory is the Tingutinskaya forest estate with pines, oaks, elms and ash trees. In 1887 - 1900, the forest belts had been planted on the watersheds of the Medveditsa (the tributary of the Don River, the Tersa and the Schelka). Up to 1917, there were planted 2,3 thousand ha of forests on the territory of the contemporary Volgograd region which reinforced more than 5,000 ha of sands.

In 1935, the works had begun to create a green zone in Volgograd (Stalingrad), the decree of the USSR government adopted a plan on field protective foresting with the name «The Stalingrad plan of the nature reformation». It was planned to plant 5 state forest plantations, to create 380,9 thousands ha of protective forest plantation, as well as to carry out reforestation and sand reinforcement on the area of 32,7 thousands ha.

At present, the area of the planted lands in the city is being reduced, it reflects the lack of the needed plantation maintenance, the growth of the urban areas and the absorption of 
the greenery by the building sites. One should admit the present state of the urban woods as adverse. The man-made influence is expressed by the industrial and transportation pollution, the territory's climate features, non-organized recreation resulting in the degradation of the green spaces. The green community landscape in Volgograd are losing stepwise the immunity to the externalities, are infected by the invaders and diseases.

\subsubsection{Characterization of the green zone in Volgograd (Stalingrad)}

The territory directly adjacent to the urban building line is presented by the slopes of the Volga Upland and the Yergeni hills that near the Volga-Don watershed run into the plateau plain. The Volga slope is severely dissected by big ravines and balkas. The soils are lightchestnut complex, with alkaline soils from 10 to $70 \%$. At the suburban lands in Volgograd (Stalingrad), the green zone had been created including lands within the limits of the city, state forest plantation adjacent to the city, woods of economical value (oak groves) and natural ravine forests.

The most difficult are the works to plant forests within the limits of the city, where the city forests and gardens are planted. The works to create a green belt around Volgograd began in 1935.

The plantations were done on the territory of about 3 thousand ha (in full calculation) before the Great Patriotic war, including more than 1100 ha of gardens and vine-groves, about 300 ha of park forests and 1800 ha of planted forests as hedgerows and small forest areas. During the Stalingrad battle many plantations were destroyed or heavily damaged, for instance, the park plantings on the Mamayev Hill, vineyards, pine trees in part. At present, the pre-war plantings remained very few [22].

In 1958, it was decided to allocate urban lands to the state forest fund for designing and creating the shield forest plantations of the green belt. The project of the green zone creation was approved by the Decree of the Council of Ministers of the Russian Federation on the 11th of August 1962, № 1062. As a result of the carried out measures on the green zone planting, the landscape of suburban zones has been changed, the dust whirls have stopped, the gullying processes have been significantly reduced.

As of the 1st January, 1966 [22], 6800 ha of plantations were in the green zone in Volgograd. The peculiar feature of the green belt is the interchange of forest cultures and fruit gardens which was a new technique in creating green zones around cities in the southeast. The species composition in the pre-war period is represented as follows: black locust, ash-leaved maple, common elm, smooth elm, green ash, oak, acacia, fever tree, Tatarian honeysuckle, amorpha, and Tatarian maple. In the after war period, the Chinese elm and the green ash have been introduced into the species composition. The planting was done in rows, with regard to the difference in the soil moistening. There were poplar trees, birches, farther - wild pear tree, black locust, smooth elm, and golden current in the first rows. In the green belt zone, 1440 ha of fruit gardens, small fruit acreage, and vineyards.

\subsubsection{The contemporary state of the green belt of Volgograd}

According to the Forest code of the Russian Federation, the forests on the urban lands are not included in the forest estate lands but belong to the municipal forests. The major geographical units of management in the field of use, protection, conservation and regeneration of city forests are the wood farms [23, 24] the areas of which make: 


\begin{tabular}{|c|c|}
\hline Name of the wood farm & The size of its area, ha \\
\hline Traktorozavodskoye & 1076,4 \\
\hline Voroshilovskoye & 1508,6 \\
\hline Kirovskoye & 1451,6 \\
\hline Krasnoarmeyskoye & 2145,6 \\
\hline Sarpinskoye & 7657,0 \\
\hline
\end{tabular}

The considerable part of the territory of the city forests is located in the ravines (balkas). The green plantations of the city forests present an artificial plantations with various schemes of mixing hardy-shrub species (pine tree, oak, elm, maple, acacia, birch, aspen, poplar, willow, et al.) and to a lesser extent, natural forests on the ravine bottom. There are specially protected nature conservation areas (SPNA) of the regional and local significance on the lands of city forests.

The green zones of the city are the important part of the city planning structure in Volgograd and the principle structural element of its ecological frame, are included into the urban life system, are an environmental and environment protective factor ensuring the quality of life and human environment.

\section{Model of the «Smart city» by the example of Volgograd}

\subsection{Principles of building the model of the "Smart city»}

Our study showed that the Smart cities are developed in a different way depending on the location and the natural environment potential, planning features and urban priorities, actively using information and communication technologies necessary for enhancement of the quality and standard of living and the service efficiency in the economic, social and nature protection aspects. The social awareness of people is very important and their active participation in the city arrangement. Graphically, the processes of the city transformation into the smart city sphere can be followed in Fig.1. The indispensable feature of a smart city is the sustainable development aimed at forming a sustainable city - the sustainable city ensuring the efficient economy and management. The next component of the Model of the Smart city is a comfortable environment state - the Ecological city determining the local natural potential, minimization of the negative impact on the environment preserving the sustainable development with respect to propagation of the "green" ideology in all the elements of the city infrastructure and its spreading among the citizens. The natural potential of the locality by the example of Volgograd is determined by the landscape solutions of building the green belt around Volgograd to guarantee the stabilization of the ecological state of the urban environment against the climatic harm.

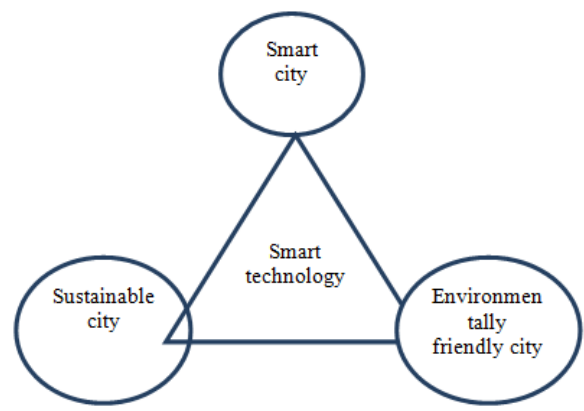

Fig. 1. Model of the Smart city development 


\subsection{Experimental design}

As the basis of the experimental design of the spatial model of the city, the principles of the developed Smart city model are taken, combining intellectual management and safety systems, green public transportation, free-of-cars yards, ecologically balanced environment. The important role is given to the recreation facilities, developed social infrastructure targeted at meeting the demands of all inhabitants. The examination of the suggested hypothesis on the need to enlarge the landscapes techniques for a comfortable environment is undergoing an experimental checkout in which the layers of designing the chosen map materials become the models by the example of Volgograd. The first layer is the scheme of planning sections in the urban territory (without the "green belt"); the second is the scheme of city development boundaries; the third layer shows the presence of green spots in the suggested "green belt" around the city. The data acquisition from the latter layer (the results processing, their interpretation and generalization) takes the significance of the objective to plan a stage of the development of the city into the Smart city sphere (Fig.2).

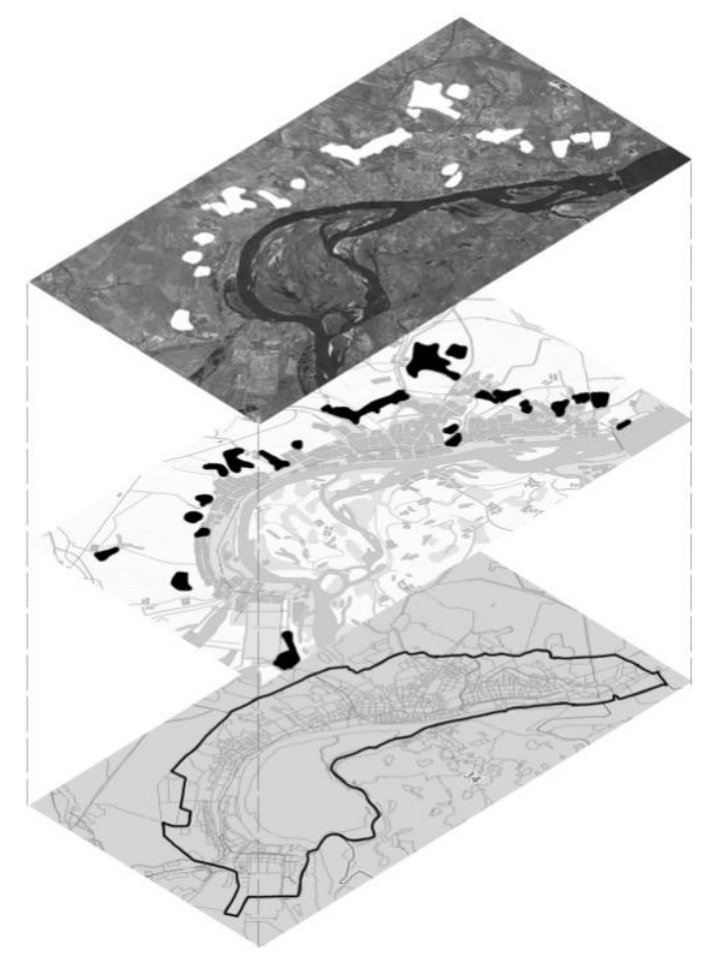

Fig. 2. Designing the modern "green belt" in Volgograd

The proposed methodology for building a landscape object around the city to neutralize the negative impact of the climate will enable to assess anew the considerable potential of using landscape techniques and the results of their introduction to energy saving technologies in accordance with which the Smart cities will present a new higher stage in the urban development. The methodological issues of the green belt designing around an urban structure can be used both in Russian and international construction under similar natural conditions when transforming a city into the "Smart city" sphere. 


\section{Conclusions}

1. The «Smart city» model has been developed including the green belt around the city to reduce the negative impact of the nature and climatic factor and to improve comfort of physical environment.

2. The methodology for organizing a landscape object is suggested - a green belt and the experimental design of the modern state of the green belt around Volgograd is carried out.

3. For the first time, an ecological analysis has been done for the historical construction of the green belt in Volgograd (Stalingrad) from the standpoint of preparation of a hypothesis to enlarge the use of landscape solutions in the energy saving technologies when developing the city into the "Smart city" concept.

\section{References}

1. URL: http://e-gov.by/smart-city/vvedenie-v-problematiku-smart-siti

2. S.Shneppe, INJOT, 2 (9), 1-3 (2014)

3. N. A. Sokolov, INJOT, 2 (9), 4-8 (2014)

4. V.J. Romanov, INJOT, 3(1), 23-29 (2015)

5. A.M. Karmanov, Izvestia TulGU, 3(1), 145 - 150 (2015)

6. URL: http://green-city.su/gorod-budushego-novaya-utopiya-ili-gore-ot-uma.

7. URL: http://living.ru/magazine/living-gorod/

8. URL: http://apptractor.ru/info/articles/gorod-budushhego-umnyiy-gorod.html

9. O.B. Ganin, I.O. Ganin, «The Smart city» (2015)

10. E. Dolgikh, E. Antonov, V. Yerlich, Intelligent Enterprise, The smart cities. Perspectives of their development in Russia (2015) URL: iemag.ru/analitics/detail.php?

11. URL: http://ecolife.ru/skolkovo-unit/7283

12. The concept of the "smart city" for Skolkovo URL: http://bytemag.ru/articles/detail.php?..

13. K.V. Porosenkova, Arhitekton, 34, 122-134 (2011)

14. Masdar-City (2011) URL: http://grammota.com/interests/masdar-....

15. 15 T.Tolmacheva, RELGA, Cities come to senses. On the «smart city» concept and the problems of its realization, no. 8 (2014)

16. J. Radulova, Vestnik SGASU, 1(18), $42-46$ (2015)

17. N.A. Lekareva, Vestnik SGASU, 1, 6-9 (2011)

18. N.A. Lekareva, A.J. Zaslavskay, The urban territorial and spatial resources. City planning strategies. (Saarbrucken, Lambert Academic Publishing, 2014)

19. T.V. Zaharova, Vestnik TSU, 2(30), 116-126 (2015)

20. N.V. Ivanova, Vestnik VGASU, 1, 15-20 (2015)

21. Forestry regulations of the Volgograd municipal wood farm (city forests) / NEA at the Volgograd Administration. Municipal institution «Gorecoles». Saratov, (2011)

22. V.V. Mironov, Forest Industries, Safeguarding forestry (Volgograd, 1998)

23. The state of the landscaped areas in Volgograd http://v102.ru/docs/1951.html

24. City forests on the map of Volgograd http://ecology.volgadmin.ru/Forest.aspx

25. N. Ivanova, O. Ganzha, Procedia Engineering, 165, 1006-1015 (2016) 